\title{
Investigation into the Utilization of ICT Facilities for Teaching Purposes among University Lecturers: Influence of Gender, Age, Qualification and Years of Teaching Experience
}

\author{
Balarabe Yushau ${ }^{1}$, Fadip Audu Nannim ${ }^{2 *}$
}

\author{
${ }^{1}$ Science Education Department, Abubakar Tafawa Balewa University, Bauchi, NIGERIA \\ ${ }^{2}$ Department of Science Education, University of Nigeria, Nsukka, NIGERIA \\ ^Corresponding Author: nfadip@gmail.com
}

Citation: Yushau, B., \& Nannim, F. A. (2020). Investigation into the Utilization of ICT Facilities for Teaching Purposes among University Lecturers: Influence of Gender, Age, Qualification and Years of Teaching Experience. Pedagogical Research, 5(2), em0054. https://doi.org/10.29333/pr/7845

\begin{tabular}{|c|c|}
\hline ARTICLE INFO & ABSTRACT \\
\hline Received: 8 Jan. 2020 & This study investigates lecturers' level of utilization of ICT facilities for teaching purposes in Nigerian universities. \\
\hline Accepted: 25 Feb. 2020 & $\begin{array}{l}\text { A descriptive survey design was adopted for the study. And a questionnaire with a reliability of } 0.907 \text { was used for } \\
\text { data collection. Data was collected at the Abubakar Tafawa Balewa University, Bauchi from a sample of } 433 \\
\text { lecturers out of a population of } 928 \text {. The results show that lecturers have the knowledge of using ICT facilities in } \\
\text { teaching, however, they rarely use them in teaching. It was also found that lecturers' age and years of teaching } \\
\text { experiences were significant factors influencing the level of ICT utilization in teaching. However, no significant } \\
\text { difference was found due to gender and educational qualification. It was recommended among others that there } \\
\text { should be regular sensitization programmes on the importance of using ICT facilities as it promotes students' } \\
\text { learning and enhance their academic achievement. }\end{array}$ \\
\hline
\end{tabular}

Keywords: lecturers, level of utilization, ICT, teaching, university

\section{INTRODUCTION}

The advent of various ICT facilities has brought substantial changes globally within the educational system. This development has given rise to a lot of investment in various kinds of ICT facilities for teaching and learning. The availability of these facilities in higher institutions has proven to enhance teaching and learning (Hamilton-Ekeke \& Mbachu, 2015); enabled self-paced learning (Shahmir, Hamidi \& Bagherzadeh, 2011); removed the time and space barriers for learning (Oyovwe-Tinuoye \& Adogbeji, 2013; Krishnaveni \& Meenakumari, 2010). Furthermore, studies have shown that students' learning and teachers' teaching are enhanced with these facilities (Apagu \& Wakili, 2015; Stephen, 2013).

ICT is now used in various educational aspects for enriching the quality of teaching and learning. The resourcefulness of ICT to academic staff of higher institution has also been reported (Hamilton-Ekeke \& Mbachu, 2015). And studies have shown that the integration of ICT in teaching offers different forms of Multimedia channels that provide variety of approaches and expertise (Nusir, Alsmadi, Al-Kabi \& Sharadgah, 2013). The use of ICT in teaching has also been found to be relevant in the area of offering guidance for students self-learning; critical evaluation of students' performance and facilitation of high-quality skills for communication (Barakabitze, 2014).

Considering the benefits of ICT, the Federal Government of Nigeria developed an ICT policy in 2001. This policy led to the establishment of the National Information Technology Development Agency (NITDA). Among the objectives of NITDA are; to ensure that ICT resources are readily available to promote efficient national development; and to integrate ICT into the mainstream of education and training (NITDA, 2017).

However, studies relating to lecturers' level of utilization of ICT facilities for teaching purposes has presented conflicting results. Some have shown low level of utilization of ICT in teaching (Olelewe \& Okwor, 2017; Archibong, Ogbiji \& Aniaobi-Idem, 2010; Nwachukwu \& Asom, 2015). Others are pointing to the fact that the utilization level is high (Enakrire \& Ocholla, 2017; Emeasoba \& Ezenwafor, 2015). These seems to indicate that studies concerning the level of utilization of ICT in teaching is inconclusive, and varied from one university to the other.

Since studies have also shown that ICT facilities for teaching purposes are available in universities (Nannim \& Yushau, 2019; Agboola, Okorie, Omotoso, Bamigboye \& Bello, 2018; Olelewe \& Okwor, 2017), it is natural to expect that the lecturers are utilizing these facilities in teaching. It is against this background that the researchers investigate lecturers' level and extent of utilization of 
ICT facilities for teaching purposes in ATBU Bauchi, Nigeria. The study also investigated the influence of gender, age, qualification and years of teaching experience on lecturers' level of ICT utilization in teaching.

\section{Purpose of the Study}

The purpose of this study is to investigate lecturers' level and extent of utilization of ICT facilities for teaching purposes in Abubakar Tafawa Balewa University (ATBU), Bauchi. Furthermore, the study investigates the influence of gender, age, qualification and years of teaching experience on lecturers' level of ICT utilization in teaching.

\section{Literature Review}

People are increasingly depending on ICT for their daily activities, yet, the utilization of these facilities in teaching is not widely in practice, though this varies between institutions and between the staff of the same institution (Jumare et al., 2017; Amusa \& Atinmo, 2016; Archibong et al., 2010). Review of related literature with respect to lecturers' level of utilization of ICT facilities in teaching has presented contradicting findings. Some studies found high level of utilization of ICT facilities for academic purposes, while others are pointing to the fact that the level of utilization is low.

For instance, in a study conducted by Emeasoba and Ezenwafor (2015), it was found that lecturers highly utilized computers in their teaching. And a similar result was equally reported by Tezci (2009). However, Olelewe and Okwor (2017) found that lecturers are not utilizing ICT facilities in their teaching. A similar low utilization of ICT facilities in teaching was earlier reported by Akuegwu, Ntukidem, Ntukidem and Jaja (2011), Agbatogun (2013) and Amusa and Atinmo (2016). Some studies have reported the reasons of low utilization of ICT facilities in teaching to be mainly lack of computer knowledge and skills for effective utilization of ICT in teaching (Olelewe and Okwor, 2017; Nwachukwu \& Asom, 2015; Atsumbe, Raymond and Duhu, 2012). While others reported lack of institutional support (Al-dheleai, Baki, Tasir, \& Al-rahmi, 2019; Enakrire \& Ocholla, 2017).

Studies have shown that gender stereotypes hinder women's active utilization of ICT (Buskens \& Webb, 2009; Edwina, 2005). It is also a general believe that women are lagging behind when it comes to the use of ICT (Hallberg, Kulecho, Kulecho \& Okoth, 2011). For example, male lecturers were found to use ICT facilities most as compared to their female counterparts (Mahdi \& AlDera, 2013). Similarly, Tezci (2009) found significant influence of gender on the level of utilization of ICT facilities by teachers. However, Agbatogun (2013) did not find any significant influence of gender on lecturers' use of ICT facilities.

It has also been shown that age is a strong factor that influences ICT usage in teaching. Roger's diffusion of innovation theory posited that age of individuals plays an important role in their adoption and use of technology. The younger individuals are the more likely to accept and use a technology compared to the older individuals (Rogers, 2003). What this mean is that younger lecturers are expected to use more of the technology in their teaching since they are considered technology freak (enthusiast). For instance, studies have shown that older teachers are less confident with using computers as compared to their younger counterpart (Teo, Lee \& Chai, 2008). While, some other studies have shown that age is not a determining factor in use of ICT in teaching (Mahdi \& Al-Dera, 2013; Tezci, 2009).

Years of teaching experience has also been found to be an influential factor in determining the use of ICT facilities by teachers. Study conducted by Egbert, Paulus and Nakamichi (2002) show that teachers with longer years of working experience utilize ICT facilities most. Also, Olafare, Adeyanju and Fakorede (2018) in their study found a significant difference between the less experienced and the experienced lecturers. However, the less experienced lecturers were found to be doing better in utilization of ICT for academic purposes. Tezci (2009) has found that the less the years of experience, the higher the knowledge and use of ICT by teachers. This has been attributed to the enthusiasm and openness of the youths towards technology (Onansanya et al., 2010; Tezci, 2009). On the other hand, some studies have not found years of experience as a determining factor for the utilization of ICT facilities in teaching (Mahdi \& Al-Dera, 2013; Niederhauser \& Stoddart, 2001).

Another factor that was found to play a role in the utilization of ICT facilities in teaching is the teachers' academic qualifications. In a study conducted by Agbatogun (2013), it was found that academic qualification is an influential factor that is a predictor of use of ICT in teaching. Similarly, Olafare et al. (2018) also found lecturers with first degree had a positive attitude towards the use of ICT than those with higher qualification. On the contrary, Gombe, Jega, Dahiru, Aji and Sani (2016) found no significant difference in the utilization of ICT based on lecturers' qualification, though lecturers with Ph.D qualification had a slightly higher mean rating, followed by those with Masters' degree, while those with Bachelors' degrees had the least mean rating.

Therefore, as a result of these contradictory findings in literature, this study investigates the level and extent of utilization of ICT facilities for teaching purposes among lectures of Abubakar Tafawa Balewa University, Bauchi. Also, the study looks into the influence of gender, age, years of teaching experience and academic qualification on lecturers' level of utilization of ICT teaching facilities.

\section{METHOD}

The methodology adopted for this study is the quantitative method, specifically the descriptive survey design. The population of this study is 928 lecturers of Abubakar Tafawa Balewa University, Bauchi. A sample of 500 lecturers were selected for the study using a stratified sampling technique. Out of 500 questionnaire administered to the lecturers, 433 questionnaire were successfully completed and returned giving the response rate of $86.6 \%$. The demographic information was elicited through the part $A$ of the survey. Part B of the instrument consists of items on the level and extent of utilization of ICT facilities among lecturers. Section 1 of part B was formulated to help the researchers in ascertaining the level at which lecturers use ICT teaching facilities in ATBU Bauchi. The section 1 of part B of the instrument was adapted from ICT self-audit chart (Johnston-Wilder \& Pimm, 2006, p. 136). 
Section 2 was designed to determine the extent to which the available ICT teaching facilities are being utilized by lecturers. (See Appendix A for details). The instrument was validated and had a reliability index of 0.907 .

In this study, Level of utilization operationally mean how the teachers utilize their ICT knowledge in teaching. While Extent of utilization in this study means the frequency of use of ICT facilities in teaching.

\section{RESULTS}

\section{Demographic Variables}

The lecturers' demographic data of the 433 respondents is in Table 1. Most of the participants were male 331 (76.4\%) while $102(23.6 \%)$ were female. Most of the respondents were Age between 34-43 years 207 (47\%). Majority of the respondents holds Masters' Degree 302 (69.7\%). Also, most of the respondents have their years of teaching experience between 1-8 years. See Table 1 for details.

Table 1. Lecturers Demographic Information

\begin{tabular}{|c|c|c|c|}
\hline Category & Groups & Number of participants & Percentage \\
\hline \multirow{3}{*}{ Gender } & Male & 331 & $76.4 \%$ \\
\hline & Female & 102 & $23.6 \%$ \\
\hline & Total & 433 & $100 \%$ \\
\hline \multirow{5}{*}{ Age } & $25-33$ years & 114 & $26.3 \%$ \\
\hline & $34-43$ years & 207 & $47.8 \%$ \\
\hline & 44-53 years & 90 & $20.8 \%$ \\
\hline & Above 53 years & 22 & $5.1 \%$ \\
\hline & Total & 433 & $100 \%$ \\
\hline \multirow{4}{*}{ Qualification } & Ph.D & 78 & $18.0 \%$ \\
\hline & Master Degree & 302 & $69.7 \%$ \\
\hline & Bachelors' Degree & 53 & $12.2 \%$ \\
\hline & Total & 433 & $100 \%$ \\
\hline \multirow{5}{*}{ Years of Teaching Experience } & $1-8$ years & 265 & $61.2 \%$ \\
\hline & $9-16$ years & 121 & $27.9 \%$ \\
\hline & $17-25$ years & 38 & $8.8 \%$ \\
\hline & Above 25 years & 9 & $2.1 \%$ \\
\hline & Total & 433 & $100 \%$ \\
\hline
\end{tabular}

\section{Levels of Utilization of ICT Facilities for Teaching Purposes}

The level of utilization of ICT facilities for teaching purposes in ATBU Bauchi is presented in Table 2. Frequency count, percentage, mean and Standard deviation was computed for each of the items, and remark provided.

Table 2. The Frequency Distribution and Means of Lecturers' Level of Utilization of ICT Facilities for Teaching Purposes

\begin{tabular}{|c|c|c|c|c|c|c|c|}
\hline Items & $\begin{array}{l}\text { I cannot } \\
\text { Use it }\end{array}$ & $\begin{array}{l}\text { I can Use it But } \\
\text { Not in Teaching }\end{array}$ & $\begin{array}{l}\text { I Can Use it in } \\
\text { Teaching }\end{array}$ & $\begin{array}{l}\text { I have Used it } \\
\text { in Teaching }\end{array}$ & Mean & SD & Remark \\
\hline Microsoft word & $4(0.9 \%)$ & $98(22.9 \%)$ & $187(43.2 \%)$ & $144(33.3 \%)$ & 3.09 & 0.77 & ICUT \\
\hline Microsoft Excel & $6(1.4 \%)$ & 75 (17.3\%) & $199(46.0 \%)$ & $153(35.3 \%)$ & 3.15 & 0.75 & ICUT \\
\hline Microsoft PowerPoint & $7(1.6 \%)$ & $80(18.5 \%)$ & $190(43.9 \%)$ & $156(36.0 \%)$ & 3.14 & 0.77 & ICUT \\
\hline Google Docs & $97(22.4 \%)$ & $160(37.0 \%)$ & $133(30.7 \%)$ & $43(9.9 \%)$ & 2.28 & 0.92 & IHUBNT \\
\hline Google Sheets & $177(40.9 \%)$ & $115(26.6 \%)$ & $100(23.1 \%)$ & 41 (9.5\%) & 2.01 & 1.01 & IHUBNT \\
\hline Google Slides & $169(39.0 \%)$ & $125(28.9 \%)$ & $100(23.1 \%)$ & $39(9.0 \%)$ & 2.02 & 0.99 & IHUBNT \\
\hline Google Forms & $174(40.2 \%)$ & $125(28.9 \%)$ & $103(23.8 \%)$ & $31(7.2 \%)$ & 1.98 & 0.96 & IHUBNT \\
\hline PDF & $41(9.5 \%)$ & $182(42.0 \%)$ & $143(33.0 \%)$ & $67(15.5 \%)$ & 2.55 & 0.87 & ICUT \\
\hline $\begin{array}{c}\text { Electronic white board/ Smart Board (Triumph Board, } \\
\text { Genee touch e.t.c) }\end{array}$ & $40(9.2 \%)$ & $46(10.6 \%)$ & $135(31.2 \%)$ & $212(49.0 \%)$ & 3.20 & 0.96 & ICUT \\
\hline $\begin{array}{c}\text { Graphic Packages (e.g Adobe Photoshop, Corel Draw, } \\
\text { AutoCAD, Adobe framework, 3D movie maker, PC } \\
\text { paintbrush e.t.c) }\end{array}$ & 49 (11.3\%) & $157(36.3 \%)$ & $179(41.3 \%)$ & $48(11.1 \%)$ & 2.52 & 0.84 & ICUT \\
\hline Statistical Packages (SPSS, Minitab e.t.c) & $170(39.3 \%)$ & $119(27.5 \%)$ & $99(22.9 \%)$ & $45(10.4 \%)$ & 2.04 & 1.02 & IHUBNT \\
\hline $\begin{array}{c}\text { Learning Management Systems (e.g Google Classroom, } \\
\text { Moodle e.t.c.) }\end{array}$ & $189(43.6 \%)$ & $152(35.1 \%)$ & $78(18.0 \%)$ & $14(3.2 \%)$ & 1.81 & 0.84 & IHUBNT \\
\hline $\begin{array}{c}\text { Programming/ Simulation Software (C, C++, Java, } \\
\text { Matlab, e.t.c.) }\end{array}$ & $102(23.6 \%)$ & $184(42.5 \%)$ & $117(27.0 \%)$ & $30(6.9 \%)$ & 2.17 & 0.87 & IHUBNT \\
\hline Internet & $12(2.8 \%)$ & $148(34.2 \%)$ & $153(35.3 \%)$ & $120(27.7 \%)$ & 2.88 & 0.85 & ICUT \\
\hline External Devices e.g flask disk, CD-ROM, Modem & $32(7.4 \%)$ & $80(18.5 \%)$ & $205(47.3 \%)$ & $116(26.8 \%)$ & 2.94 & 0.86 & ICUT \\
\hline Cluster Mean & & & & & 2.52 & 0.54 & \\
\hline
\end{tabular}

Key: SD=Standard Deviation, I Cannot Use it (ICNU)=1.00-1.49, I Have Use it But Not in Teaching (IHUBNT)=1.50-2.49, I Can Use it in Teaching (ICUT) $=2.50-3.49$, I Have Use it in Teaching (IHUT) $=3.50-4.00$

Table 2 shows the lecturers' level of use of ICT facilities for teaching purposes. The lecturers' response showed that the Electronic white board/ Smart Board such as Triumph Board and Genee touch (Mean=3.20, SD=0.96) has the highest level of 
utilization in teaching among lecturers. The result shows that $212(49.0 \%)$ of the lecturers who participated in the study have used the ICT device in their teaching. The least used ICT facilities are the Learning Management Systems such as Google Classroom and Moodle (Mean=1.81, SD=0.84) where $189(43.6 \%)$ of the lecturers indicated that they cannot use it in teaching. The cluster mean of 2.52 showed that overall, the lecturers can use ICT facilities in teaching however, they have not been using them.

\section{Extent of utilization of ICT facilities for teaching purposes}

The frequency count, percentage, mean and Standard deviation of the responses of lecturers on their extent of utilization of ICT facilities for teaching purposes is presented in Table 3.

Table 3. The Frequency Distribution and Means of Lecturers' Extent of Utilization of ICT Facilities for Teaching Purposes

\begin{tabular}{|c|c|c|c|c|c|c|c|}
\hline Items & Not at All & $\begin{array}{l}\text { Few Times } \\
\text { a Month }\end{array}$ & $\begin{array}{c}\text { Few Times a } \\
\text { Week }\end{array}$ & $\begin{array}{c}\text { Almost } \\
\text { Every Day }\end{array}$ & Mean & SD & Remark \\
\hline Desktop/Laptop Computers & $3(0.7 \%)$ & $16(3.7 \%)$ & $81(18.7 \%)$ & $333(76.9 \%)$ & 3.72 & 0.56 & AED \\
\hline Handhelds/Tablets computers (iPad)/other mobile devices & $4(0.9 \%)$ & $31(7.23 \%)$ & $91(21.0 \%)$ & $307(70.9 \%)$ & 3.62 & 0.66 & AED \\
\hline Electronic/ Smart Board (Triumph Board, Genee touch e.t.c) & $265(61.2 \%)$ & $152(35.1 \%)$ & $16(3.7 \%)$ & $0(0.0 \%)$ & 1.42 & 0.57 & NAA \\
\hline Digital Camera & $268(61.9 \%)$ & $149(34.4 \%)$ & $16(3.7 \%)$ & $0(0.0 \%)$ & 1.41 & 0.56 & NAA \\
\hline Hard Disk Drive (External) & $18(4.2 \%)$ & $132(30.5 \%)$ & $192(44.3 \%)$ & $91(21.0 \%)$ & 2.82 & 0.81 & FTW \\
\hline Flash Drive & $8(1.8 \%)$ & $85(19.6 \%)$ & $222(51.3 \%)$ & $118(27.3 \%)$ & 3.04 & 0.74 & FTW \\
\hline CD/DVD & $21(4.8 \%)$ & $101(23.3 \%)$ & $187(43.2 \%)$ & $124(28.6 \%)$ & 2.96 & 0.84 & FTW \\
\hline Internet & $0(0.0 \%)$ & $9(2.1 \%)$ & $119(27.5 \%)$ & $305(70.4 \%)$ & 3.68 & 0.51 & AED \\
\hline University Website & $6(1.4 \%)$ & $42(9.7 \%)$ & $141(32.6 \%)$ & $244(56.4 \%)$ & 3.44 & 0.72 & FTW \\
\hline E-mail (Gmail, Yahoo Mail e.t.c) & $6(1.4 \%)$ & $65(15.0 \%)$ & $200(46.2 \%)$ & $162(37.4 \%)$ & 3.20 & 0.74 & FTW \\
\hline Digital Signage & $343(79.2 \%)$ & $86(19.9 \%)$ & $4(0.9 \%)$ & $0(0.0 \%)$ & 1.22 & 0.43 & NAA \\
\hline Video conferencing facilities (e.g NgREN) & $325(75.1 \%)$ & $105(24.2 \%)$ & $3(0.7 \%)$ & $0(0.0 \%)$ & 1.27 & 0.47 & NAA \\
\hline $\begin{array}{l}\text { Microsoft Office Packages (Ms Word, Ms Excel, Ms PowerPoint, } \\
\text { Ms Access) }\end{array}$ & $34(7.9 \%)$ & $49(11.3 \%)$ & $194(44.8 \%)$ & $156(36.0 \%)$ & 3.09 & 0.88 & FTW \\
\hline Statistical Packages (e.g Minitap, SPSS, MSTAT) & $275(63.5 \%)$ & $142(33.0 \%)$ & $15(3.5 \%)$ & $0(0.0 \%)$ & 1.40 & 0.55 & NAA \\
\hline Graphic Packages (e.g. Adobe Photoshop, Corel Draw, AutoCAD) & $270(62.4 \%)$ & $148(34.2 \%)$ & $15(3.5 \%)$ & $0(0.0 \%)$ & 1.41 & 0.56 & NAA \\
\hline Learning Management Systems (e.g Google Classroom, Moodle) & $273(63.0 \%)$ & $145(33.5 \%)$ & $15(3.5 \%)$ & $0(0.0 \%)$ & 1.40 & 0.57 & NAA \\
\hline Programming/ Simulation Software (C, C++, Java, Matlab, e.t.c.) & $267(61.7 \%)$ & $149(34.4 \%)$ & $17(3.9 \%)$ & $0(0.0 \%)$ & 1.42 & 0.57 & NAA \\
\hline Cluster Mean & & & & & 2.38 & 0.28 & \\
\hline
\end{tabular}

Key: SD=Standard Deviation, Not at All $(\mathbf{N A A})=1.00-1.49$, Few Times a Month $(\boldsymbol{F T M})=1.50-2.49$, Few Times a Week $(\boldsymbol{F T W})=2.50-3.49$, Almost Every Day $(\boldsymbol{A E D})=3.50-4.00$

Results in Table 3 show that the most frequently used ICT facility was the Desktop computer/Laptop (M=3.72, SD=0.56), which is closely followed by Internet $(M=3.68, S D=0.51)$ and Handheld/Tablets computers $(M=3.62, S D=0.66)$. The least used ICT facilities are Digital signage and videoconferencing facilities with means 1.22 and 1.27 respectively. The cluster mean of 2.38 shows that the extent (frequency) of use of ICT facilities among ATBU lecturers is low.

\section{The Influence of Gender on ATBU Lecturers' Level of Utilization of ICT Facilities for Teaching Purposes}

Table 4 shows the influence of gender on ATBU lecturers' level of utilization of ICT facilities for teaching purposes. The result show that male lecturers had mean ratings of $2.54, S D=0.56$ while their female counterparts had mean ratings of $2.34, S D=0.47$.

Table 4. Mean Ratings on Influence of Gender on ATBU Lecturers' Level of Utilization of ICT Facilities for Teaching Purposes

\begin{tabular}{cccc}
\hline Gender & N & Mean & \\
\hline Male & 331 & 2.54 & \\
\hline Female & 102 & 2.45 & 0.56 \\
\hline
\end{tabular}

The result in Table 4 shows that the male lecturers had a slightly higher mean rating compared to their female counterparts. An independent t-test run on influence of ATBU lecturers gender on their level of utilization of ICT facilities in teaching shows that there is no significant difference between the mean ratings of male and female lecturers $t_{(2,431)}=1.50, p=0.14$ ( 2 -tailed). This means that the male and female lecturers do not differ in their level of utilization of ICT facilities for teaching purposes.

\section{The Influence of Age on ATBU Lecturers' Level of Utilization of ICT Facilities for Teaching Purposes}

Table 5 shows that lecturers who are more advanced in age had higher mean ratings compared to those who are younger in age. A Oneway ANOVA was conducted at 0.05 level of significance to compare the mean difference across the age groups. The result shows that there is a statistically significant difference in the mean scores ratings of the four age groups, $F_{(3,429)}=7.233$, $P=$ 0.000 . This shows that the lecturers differ in their level of utilization of ICT facilities for teaching purposes based on age. Thus, age is an influencing factor. A Post Hoc Test was conducted to determine where the difference lies among the groups. Table 6 shows the result of the analysis on Scheffe's post-hoc and the mean difference.

Table 5. Mean Ratings on Influence of Age on Lecturers' Level of Utilization of ICT Facilities for Teaching Purposes

\begin{tabular}{ccccc}
\hline Age Range & $\mathbf{N}$ & Mean & SD \\
\hline 25-33 years & 114 & 2.41 & \\
\hline $34-43$ years & 207 & 2.48 & \\
\hline 44-53 years & 90 & 2.64 & \\
\hline Above 53 years & 22 & 2.89 & 0.54 \\
\hline Total & 433 & 2.52 & 0.59 \\
\hline
\end{tabular}


Table 6. Scheffe's Analysis of Significant Difference of Lecturers' Level of Utilization of ICT Facilities in Teaching based on Age

\begin{tabular}{|c|c|c|c|c|}
\hline (I) Age Range & (J) Age Range & Mean Difference (I-J) & Std. Error & Sig. \\
\hline \multirow{3}{*}{$25-33$ years } & $34-43$ years & -.07418 & .06164 & .694 \\
\hline & 44-53 years & $-.23244^{\star}$ & .07452 & .022 \\
\hline & Above 53 years & $-.48341^{\star}$ & .12307 & .002 \\
\hline \multirow{3}{*}{$34-43$ years } & $25-33$ years & .07418 & .06164 & .694 \\
\hline & $44-53$ years & -.15826 & .06673 & .133 \\
\hline & Above 53 years & $-.40924^{\star}$ & .11851 & .008 \\
\hline \multirow{3}{*}{ 44-53 years } & $25-33$ years & $.23244^{\star}$ & .07452 & .022 \\
\hline & $34-43$ years & .15826 & .06673 & .133 \\
\hline & Above 53 years & -.25098 & .12569 & .264 \\
\hline \multirow{3}{*}{ Above 53 years } & $25-33$ years & $.48341^{\star}$ & .12307 & .002 \\
\hline & $34-43$ years & $.40924^{\star}$ & .11851 & .008 \\
\hline & $44-53$ years & .25098 & .12569 & .264 \\
\hline
\end{tabular}

*. The mean difference is significant at the 0.05 level

The result of the post-hoc analysis of the four age groups in Table 6 infers that there is a significant difference on level of utilization of ICT facilities among lecturers within the age of 25-33 years and 45-53 years. Also, there was a significant difference between the age range of 25-33 year and Above 53 years. Moreover, it can be inferred that there was a significant different between the age range of 34-43 years and the age range of above 53 years. Therefore, the Scheffe's analysis established a significant difference between lecturers' level of utilization of ICT facilities for teaching purposes based on age. This post-hoc test established that lecturers who are more advanced in age utilized more ICT in their teaching as compared to those younger in age.

\section{The Influence of Years of Teaching Experiences on ATBU Lecturers' Level of Utilization of ICT Facilities for Teaching Purposes}

Table 7 shows that, lecturers with higher years of teaching experiences (Above 25 years) had higher mean rating (2.96) compared to those with smaller years of teaching experiences (1-8 years) who had means rating of 2.42. Oneway ANOVA was conducted at 0.05 level of significance to compare the mean ratings of lecturers based on difference in years of teaching experience. The result shows a statistical significant difference in lecturers level of utilization of ICT facilities for teaching purposes based on years of teaching experiences, $F_{(3,429)}=9.493, P=0.00$. This implies that the lecturers differ significantly on level of utilization of ICT facilities with respect to years of teaching experience. The Scheffe's post-hoc test was conducted to determine where the difference lies among the lecturers' years of teaching experience. Table 8 shows the result of the post-hoc analysis and the mean difference.

Table 7. Mean Ratings on Influence of Years of Teaching Experience on ATBU Lecturers' Level of Utilization of ICT Facilities for Teaching Purposes

\begin{tabular}{|c|c|c|c|}
\hline Years of Teaching & $\mathbf{N}$ & Mean & SD \\
\hline $1-8$ years & 265 & 2.42 & 0.49 \\
\hline 9-16 years & 121 & 2.67 & 0.58 \\
\hline $17-25$ years & 38 & 2.66 & 0.57 \\
\hline Above 25 years & 9 & 2.96 & 0.58 \\
\hline Total & 433 & 2.52 & 0.54 \\
\hline
\end{tabular}

The Scheffe's post-hoc analysis in Table 8 shows that there was a significant difference between lecturers with 1-8 years of teaching experience and those with 9-16 years $(p=0.00)$. Also, there was a significant difference between those with $1-8$ years and those with above 25 years of teaching experiences $(p=0.25)$. The Scheffe's post-hoc therefore established a significant relationship between lecturers with lower years of teaching experience and those with higher years of teaching experiences with respect to level utilization of ICT facilities for teaching purposes. This mean that lecturers with longer years of teaching experience have higher level of utilization of ICT facilities in teaching compared to lecturers with lower years of teaching experience.

Table 8. Scheffe's Post-hoc Analysis of Significant Difference of Lecturers' Knowledge of ICT Facilities for Teaching Purposes Based on Years of Teaching Experiences

\begin{tabular}{|c|c|c|c|c|}
\hline (I) Years of Teaching Experience & (J) Years of Teaching Experience & Mean Difference (I-J) & Std. Error & Sig. \\
\hline \multirow{3}{*}{$1-8$ years } & $9-16$ years & $-.24570^{\star}$ & .05755 & .000 \\
\hline & $17-25$ years & -.24781 & .09099 & .061 \\
\hline & Above 25 years & $-.54586^{\star}$ & .17780 & .025 \\
\hline \multirow{3}{*}{$9-16$ years } & $1-8$ years & $.24570^{\star}$ & .05755 & .000 \\
\hline & $17-25$ years & -.00210 & .09755 & 1.000 \\
\hline & Above 25 years & -.30015 & .18124 & .434 \\
\hline \multirow{3}{*}{$17-25$ years } & $1-8$ years & .24781 & .09099 & .061 \\
\hline & 9-16 years & .00210 & .09755 & 1.000 \\
\hline & Above 25 years & -.29805 & .19446 & .504 \\
\hline \multirow{3}{*}{ Above 25 years } & 1-8 years & $.54586^{*}$ & .17780 & .025 \\
\hline & $9-16$ years & .30015 & .18124 & .434 \\
\hline & $17-25$ years & .29805 & .19446 & .504 \\
\hline
\end{tabular}

\footnotetext{
${ }^{\star}$. The mean difference is significant at the 0.05 level
} 


\section{The Influence of Lecturers' Qualification on their Level of Utilization of ICT Facilities for Teaching Purposes}

To determine the influence of lecturers' qualification on their level utilization of ICT facilities for teaching purposes, the mean ratings of their responses were computed.

Table 9 shows that lecturers with Ph.D. qualifications had mean ratings of 2.62 (SD=0.55), Masters' Degree holders had mean ratings of $2.51(S D=0.54)$, while those with Bachelors' degree had mean ratings of $2.42(S D=0.47)$. This result shows that lecturers with higher qualification had a slightly higher mean ratings than those with lower qualification. A Oneway ANOVA conducted to determine if there was a significant difference in lecturers response based on their qualification shows that there is no statistically significant difference in lecturers level of utilization of ICT facilities for teaching purposes $F_{(2,430)}=2.265$, $p=0.105$. This means that the lecturers do not differ in their level of utilization of ICT facilities for teaching purposes based on qualification.

Table 9. Mean Ratings on Influence of Lecturers' Qualification on their Level of Utilization of ICT Facilities for Teaching Purposes

\begin{tabular}{cccc}
\hline Qualification & N & Mean & Std. Deviation \\
\hline Ph.D. & 78 & 2.62 & 0.55 \\
\hline Master Degree & 302 & 2.51 & 0.54 \\
\hline Bachelor's Degree & 53 & 2.42 & 0.47 \\
\hline Total & $\mathbf{4 3 3}$ & $\mathbf{2 . 5 2}$ & \\
\hline
\end{tabular}

\section{DISCUSSION}

The purpose of this study was to investigate the level and extent of lecturers' utilization of ICT facilities in teaching, as well as the influence of gender, age, years of teaching experience and educational qualification on level of utilization of ICT facilities in teaching.

The demographic information in Table 1 showed that there were 331 (76.4\%) male and 102 (23.6\%) female lecturers. Also, most of the respondents were Age between 34-43 years 207 (47\%). Also, a majority 302 (69.7\%) of the respondent holds Masters' Degree.

Findings based on level of utilization of ICT facilities in Table 2 showed that lecturers in ATBU can use ICT facilities for teaching purposes. The ICT facilities with the highest level of utilization is the Electronic white board/ Smart Board (Triumph Board and Genee touch) with Mean=3.20 ( $S D=0.96)$, followed by MS Excel, MS PowerPoint, MS Word, external devices, internet, PDF and graphic packages. The least used ICT facilities is the Learning Management Systems (Google Classroom and Moodle) with Mean=1.81 (SD=0.84). The cluster mean of 2.52 showed that overall, the lecturers can use ICT facilities in teaching. However, they have not been using them in actual teaching. This implies that, although they can use these facilities for teaching purposes, a number of them have not been using it in their teaching. Few lecturers actually used these ICT facilities in their teaching. For example, only $33.3 \%, 35.3 \%, 36 \%, 49 \%$ and $27 \%$ of the lecturers indicated that they have used Microsoft word, Microsoft excel, Microsoft PowerPoint, Smart Board and the internet respectively. The least response was 14 (3.2\%) of the participants who indicated that they have used Learning Management System (LMS) in their teaching. This is despite the fact that LMS such as Moodle and Google Classroom are available free of charge in the university for the lecturers' use (See Nannim \& Yushau, 2019). Similalrly, study conducted by Nannim, Yushau and Gital (2018) had shown that lecturers are aware of the availability of these facilities. Therefore, the low level of utilization of these facilities in teaching could be due to lack of technical knowledge of how to use these facilities in actual teaching. It could also be attributed to institutional factors such as not providing the enabling environment to use these facilities or individual factor such as lack of will from the side of the lecturers to use the facilities in teaching. It could also be due to heavy course loads that left lecturers with less time to organize and plan how to use the available facilities in teaching. This result is similar to findings of previous studies (Enakrire \& Ocholla, 2017; Emeasoba \& Ezenwafor, 2015) which show that lecturers can use ICT facilities in universities. However, it disagrees with (Olelewe \& Okwor, 2017; Nwachukwu \& Asom, 2015; Agbatogun, 2013; Atsumbe et al., 2012) whose research found that most teachers cannot use ICT facilities in teaching.

The result in Table 3 is on extent of utilization of ICT facilities for teaching purposes. The result showed that the most frequently used ICT facility by the lecturers in the University is the Desktop computer/Laptop $(M=3.72, S D=0.56)$, which was closely followed by Internet ( $M=3.68, S D=0.51)$ and Handheld/Tablets computers $(M=3.62, S D=0.66)$. The least used ICT facilities are Digital signage and videoconferencing facilities with means 1.22 and 1.27 respectively. Other ICT teaching facilities which most of the lecturers indicated that they have not been using them at all in teaching included: Smart Boards (Triumph Board and Genee touch) $(M=1.42, S D=0.57)$, programming/Simulation software $(M=1.42, S D=0.57)$, Learning Management Systems $(M=1.40, S D=0.57)$, Graphic Packages ( $M=1.41, S D=0.56)$, Statistical Packages $(M=1.40, S D=0.55)$ and Digital Camera $(M=1.41, S D=0.56)$. This finding is surprising because ATBU is a university of technology where these facilities should be used adequately in teaching. But the lecturers' response is showing otherwise. The lecturers' responses further showed that they fairly used the university website, Email, storage devices and Microsoft office packages (few Times a Week). The cluster mean of 2.38 showed that overall, the extent of use of ICT facilities among ATBU lecturers is low. This finding agrees with Jumare et al. (2017) which report low extent of use of ICT facilities in teaching. Tercy (2009) also showed that the frequency of used of ICT facilities among teachers is low. However, the result disagrees with Tella et al. (2017), Nkoyo and Egbe (2016) who both reported high extent utilization of ICT facilities among lecturers.

Result on influence of gender on lecturers' level of utilization of ICT facilities for teaching purposes in Table $\mathbf{4}$ shows that the male lecturers had a slightly higher mean (2.54) rating than their female counterparts (2.45). However, t-test result showed that there was no statistically significant difference between the male and female lecturers on their level of use of ICT facilities for teaching purposes. The result of this study agrees with previous findings (Olafare et al., 2018; Agbatogun, 2013). However, it is in 
contrast to Mahdi and Al-Dera (2013) which found a significant difference between the male and female teachers in terms of ICT use in teaching.

The result in Table 5 showed that lecturers who are older in age had higher mean ratings on level of utilization of ICT facilities in teaching as compared to the younger lecturers. Oneway ANOVA result showed that there was a significant difference between the age groups. The Scheffe's post-hoc in Table 6 inferred that there was a significant difference on level of utilization of ICT facilities among lecturers within the age of 25-33 years and 45-53 years. The result also showed a significant difference between the age range of 25-33 year and Above 53 years. It can also be deduced that there was a significant different between the age range of 34-43 years and the age range of above 53 years. The Scheffe's post hoc analysis therefore established a significant difference in lecturers' level of utilization of ICT facilities for teaching purposes based on age. This shows that the older lecturers used ICT in teaching more as compared to the younger lecturers. This could be that the older lecturers have been teaching for longer period of time, so they are aware of the pedagogical usefulness of ICT. Also, the younger lecturers could not be using ICT in teaching because they lack confidence regarding their subject area. This is in agreement with (Mahdi \& Al-Dera, 2013; Morley, 2010) whose study showed significant difference in utilization of ICT based on age. It is in contrast to Jegede (2009) which showed that there was no significant difference between younger teachers and elderly ones in their competency of use of ICT in teaching. This finding is also contrary to Rogers (2003) which says that the younger people are tech savvy individuals, therefore, they are more positively disposed to the use of ICT which is a new innovation.

The influence of years of teaching experience on ATBU lecturers' level of utilization of ICT facilities in teaching in Table 7 showed that lecturers with longer years of teaching experiences had higher level of utilization of ICT facilities in teaching compared to those with smaller years of teaching. The result also showed a significant difference between the lecturers based on years of teaching experience. Lecturers with longer years of teaching experience were found to have higher level of ICT utilization than those with lower years of teaching experience. This agrees with (Olafare et al., 2018; Tezci, 2009) who reported significant difference between lecturers on utilization of ICT based on years of teaching experience. Also, Egbert et al. (2002) reports that teachers with longer years of working experience have more knowledge on ICT facilities and use it most. However, this result disagrees with Mahdi and Al-Dera (2013) and Niederhauser and Stoddart (2001) who showed that there was no significant difference based on years of teaching experiences. The Scheffe's post-hoc test in Table 8 shows that lecturers with longer years of teaching experience had higher level of utilization of ICT facilities in teaching than those with smaller years of teaching experience. This finding is contrary to (Tezci, 2009) who showed that the less the years of teaching experience, the higher the knowledge of utilization of ICT facilities. This was attributed to the openness of youths to innovations.

The result from this investigation also shows that lecturers with Ph.D and Masters qualification had slightly higher mean ratings on level of utilization of ICT in teaching than those with Bachelors' Degree. This result is not surprising because the added qualification of the lecturers must have exposed them to many skills of using ICT in their teaching. The ANOVA result showed that there was no statistically significant different between the lecturers' level of utilization of ICT based on qualification. The result agrees with the findings of Gombe et al. (2016) who investigated the use of ICT by lecturers in the North-Western Nigeria and found no significant difference in the utilization of ICT based on lecturers' qualification. The findings of Gombe et al. (2016) also showed that lecturers with Ph.D qualification had a slightly higher mean rating, followed by those with Masters' degree, while those with Bachelors' degrees had the least mean rating. However, the result disagrees with (Olafare et al., 2018) who found a significant difference in knowledge of use of ICT by lecturers based on their qualifications.

\section{CONCLUSION AND RECOMMENDATIONS}

This study investigated the level and extent of utilization of ICT facilities by lecturers in ATBU Bauchi, Nigeria. The study found that lecturers in ATBU have the capability of using ICT facilities in teaching, however, they have not been using it in their teaching. The extent of use of ICT facilities in teaching by the lecturers was found to be low. Also, there was no significant difference on level of utilization of ICT facilities for teaching based on lecturers' gender and qualification. However, a significant difference was found based on age and years of teaching experiences of the lecturers. It was also found that lecturers with higher years of teaching experience had higher level of utilization of ICT facilities in teaching compared to those with lesser years of teaching experiences. Therefore, regular workshops aimed at increasing lecturers' level of utilization of these facilities in teaching should be organized. The workshop and training programme should also aimed at sensitizing lecturers on the importance of using ICT facilities as it promotes students' learning and enhance their academic achievement. Special interest should be on the newly recruited or less experienced lecturers.

\section{ACKNOWLEDGEMENT}

We thank our colleague's and all the authors whose works were consulted during the process of this study. This research was funded by the Tertiary Educational Trust Fund (TEDFund) Institutional Based Research.

\section{REFERENCES}

Agbatogun, A. O. (2013). Interactive Digital Technologies' Use in Southwest Nigerian Universities. Educational Technology Research and Development, 61(2), 333-357. https://doi.org/10.1007/s11423-012-9282-1 
Agboola, I. O., Okorie, C. N., Omotoso, A. O., Bamigboye, O. B., \& Bello, T. O. (2018). Electronic information usage of academics as correlate to research output in a Nigerian university of agriculture. Nigerian and RSA Library Journals, 14(1\&2), 42-55.

Akuegwu, B. A., Ntukudem, E. P., Ntukudem, P. J., \& Jaja, G. (2011). Information and Communications Technology (ICT) Facilities' Utilization for Quality Instructional Service Delivery Among University Lecturers in Nigeria. Review of Higher Education Journal in Africa, 3(1), 33-53. Retrieved from https://journal.lib.uoguelph.ca/index.php/rhea/article/view/1537

Al-dheleai, Y. M., Baki, R., Tasir, Z., \& Al-rahmi, W. M. (2019). What hinders the use of ICT among academic staff at Yemen's public universities? International Journal of Humanities and Innovation (IJHI), 2(1), 13-24. https://doi.org/10.33750/ijhi.v2i1.30

Amusa, O. I., \& Atinmo, M. (2016). Availability, Level of Use and Constraints to Use of Electronic Resources by Law Lecturers in Public Universities in Nigeria. JLIS. it, 7(3), 139-172. Retrieved from https://files.eric.ed.gov/fulltext/ED569231.pdf

Apagu, V. V., \& Wakili, B. A. (2015). Availability and utilization of ICT facilities for teaching and learning of vocational and technical education in Yobe State Technical Colleges. American Journal of Engineering Research, 4(2), 113-118. Retrieved from http://www.ajer.org/papers/v4(02)/N04201130118.pdf

Archibong, I. A., Ogbiji, J., \& Anijaobi-Idem, F. (2010). ICT competence among academic staff in universities in Cross Rivers State, Nigeria. Computer and Information Science, 3(4), 109-115. https://doi.org/10.5539/cis.v3n4p109

Atsumbe, B. N., Raymond, E., Enoch, E. B., \& Patrick, D. (2012). Availability and Utilization of e-learning Infrastructures in Federal University of Technology, Minna. Journal of Education and Practice, 3(13), 56-64. Retrieved from https://pdfs.semanticscholar.org/3d93/9019695229f37a384a0ecf7d4c921528e6e5.pdf

Barakabitze, A. A. (2014). The Context of Education Initiatives, Importance and Inhibitors of ICTs towards improving teaching and learning in Tanzania: A Critical Literature review. Information and Knowledge Management, 4(10), 83-97.

Buskens, I., Webb, A. (2009). Introduction. In I. Buskens, A. Webb (eds), African Women and ICTS: Investigating Technology, Gender and Empowerment. 1-8. Retrieved from https://idl-bnc-drc.dspacedirect.org/bitstream/handle/10625/37700/IDL-37700.pdf? sequence=1\&isAllowed $=\mathrm{y}$

Dhanarajan, G. (2002). Objectives and strategies for effective use of ICTs. Chapter-5, Technologies for Education, 58-74.

Edwina, S. (2005). Women 2000 and beyond: Gender equality and empowerment of women through ICT. United Nations Division for the Advancement of Women. Retrieved from https:/www.un.org/womenwatch/daw/public/w2000-09.05-ict-e.pdf

Egbert, J., Paulus, T., \& Nakamichi, Y. (2002). The Impact of CALL Instruction on Language Classroom Technology Use: A Foundation for Rethinking CALL Teacher Education? Language Learning \& Technology, 6(3), 108-126. Retrieved from https://scholarspace.manoa.hawaii.edu/bitstream/10125/25179/06_03_egbert.pdf

Emeasoba, N. C., \& Ezenwafor, J. I. (2014). Assessment of computer operation and networking competencies possessed by Office Technology and Management lecturers in tertiary institutions in Anambra and Enugu states Nigeria. Journal of Emerging Trends in Educational Research and Policy Studies, 5(7), 1-5. Retrieved from https://www.ingentaconnect.com/content/ sabinet/sljeteraps/2014/00000005/00000007/art00001

Enakrire, R. T., \& Ocholla, D. N. (2017). Information and communication technologies for knowledge management in academic libraries in Nigeria and South Africa. SA Journal of Information Management, 19(1), 1-9. https://doi.org/10.4102/sajim.v19i1.750

Gombe, S. Y., Jega, K. I., Aji, A. A., \& Sani A. (2016). The Use of Information and Communication Technology (ICT) by Lecturers in North-Western Nigeria. Computer Engineering and Intelligent Sytems, 7(8), 1-6. Retrieved from http://www.academia.edu/ download/51144790/Afrim_Group.pdf

Hallberg, D., Kulecho, M., Kulecho, A., \& Okoth, L. (2011). Case Studies of Kenyan Digital Villages with a Focus on Women and Girls. Journal of Language, Technology \& Entrepreneurship in Africa, 3(1), 255-273. https://doi.org/10.4314/jolte.v3i1.66724

Hamilton-Ekeke, J. T., \& Mbachu, C. E. (2015). The Place of Information, Communication and Technology (ICT) in Teaching and Learning in Nigerian Tertiary Institutions. American Journal of Educational Research, 3(3), 340-347. Retrieved from Retrieved from https://pdfs.semanticscholar.org/91b1/14272a50f44d3896c72d496f8bf5449a5305.pdf

Jegede, P. O. (2009). Age and ICT-related behaviours of higher education teachers in Nigeria. Issues in Informing Science \& Information Technology, 6, 771-778. Retrieved from http://iisit.org/Vol6/IISITv6p771-777Jegede638.pdf

Jumare, M. A., Tahir, S. M., \& Hamid, A. T. (2017). The Use of ICT in Nigerian Universities: Study of Kaduna State University, Kaduna. International Journal of Advanced Research in IT and Engineering, 6(7), 1-12. Retrieved from http://www.garph.co.uk/ IJARIE/July2017/1.pdf

Krishnaveni, R., \& Meenakumari, J. (2010). Usage of ICT for Information Administration in Higher education Institutions-A study. International Journal of Environmental Science and Development, 1(3), 282-186. https://doi.org/10.7763/IJESD.2010.V1.55

Mahdi, H. S., \& Al-Dera, A. S. A. (2013). The impact of teachers' age, gender and experience on the use of information and communication technology in EFL teaching. English Language Teaching, 6(6), 57-67. https://doi.org/10.5539/elt.v6n6p57

Morley, G. (2010). Primary Teachers and ICT: Is gender, age or experience important? System Cybernetics and Informatics, 9(7), 5-9. Retrieved from http://eprints.hud.ac.uk/8929/1/MorleyWhatpdf.pdf

Nannim, F. A., \& Yushau, B. (2019). Availability and adequacy of information and communication technology teaching facilities in Nigerian universities: The case of ATBU Bauchi. Being a conference paper presented at the 7th Annual National Conference of the Computer Educators Association of Nigeria, held between the $15^{\text {th }}$ and $18^{\text {th }}$ of October, 2019, at College Event Centre, Alvan Ikoku Federal College of Education (AIFCE), Owerri, Imo State, Nigeria. 
Nannim, F. A., Yushau, B., \& Gital, A. Y. (2018). Lecturers' level of awareness of ICT facilities for teaching purposes. African Journal of Science, Technology and Mathematics Education, 4(1), 16-24.

National Information Technology Development Agency (NITDA). (2017, February 2). NITDA Inaugurates COBIT 5 National Implementation Committee. Retrieved from https://nitda.gov.ng/2017/02/02/nitda-inaugurates-cobit-5-nationalimplementation-committee/

Niederhauser, D. S., \& Stoddart, T. (2001). Teachers' Instructional Perspectives and Use of Educational Software. Teaching and Teacher Education, 17, 15-31. https://doi.org/10.1016/S0742-051X(00)00036-6

Nkoyo, E., \& Egbe, N. (2016). Availability and Utilization of Electronic resources by postgraduate Students in a Nigerian University Library: A case study of University of Calabar, Nigeria. Information and Knowledge Management, 6(2), 60-69. Retrieved from http://www.iiste.org/Journals/index.php/IKM/article/view/28714

Nusir, S., Alsmadi, I., Al-Kabi, M., \& Sharadgah, F. (2013). Studying the impact of using multimedia interactive programs on children's ability to learn basic math skills. E-Learning and Digital Media, 10(3), 305-319. https://doi.org/10.2304/elea.2013.10.3.305

Nwachukwu, V. C., \& Asom, F. (2015). Utilization of computer technology for academic work by lecturers of university of JosNigeria. International Journal of Library and Information Science Studies, 1(2), 14-22

Olafare, F. O., Adeyanju, L. O., \& Fakorede, S. O. A. (2018). Colleges of Education Lecturers Attitude Towards the Use of Information and Communication Technology in Nigeria. MOJES: Malaysian Online Journal of Educational Sciences, 5(4), 1-12. Retrieved from https://mojes.um.edu.my/index.php/MOJES/article/download/12515/8084

Olatokun, W. M. (2007). Availability, Accessibility and Use of ICTs among Nigerian Women Academics. Malaysian Journal of Library \& Information Science, 12(2), 13-33. Retrieved from http://mojem.um.edu.my/index.php/MJLIS/article/download/6994/4652

Olelewe, C. J., \& Okwor, A. N. (2017). Lecturers' perception of interactive whiteboard for instructional delivery in tertiary institutions in Enugu State, Nigeria. Journal of Computers in Education, 4(2), 171-196. https://doi.org/10.1007/s40692-0170077-6

Onansanya, S. A., Shehu, R. A., Oduwaiye, R. O., \& Shehu, L. A. (2010). Higher Institution Lecturers Attitude Towards Integration of ICT into Teaching and Research in Nigeria. Research Journal of Information Technology, 2(1), 1-10. https://doi.org/10.3923/rjit.2010.1.10

Oyovwe-Tinuoye, G., \& Adogbeji, B. O. (2013). Information communication technologies (ICT) as an enhancing tool in quality education for transformation of individual and the nation. International Journal of Academic Research in Business and Social Sciences, 3(4), 21-32. Retrieved from http://hrmars.com/admin/pics/1714.pdf

Rogers, E. M. (2003). Diffusion of innovations (5th edition). The Free Press. New York.

Shahmir, S., Hamidi, F., \& Bagherzadeh, Z. (2011). Role of ICT in the curriculum educational system. Procedia Computer Science, 3 , 623-626. https://doi.org/10.1016/j.procs.2010.12.104

Stephen, U. A. (2013). Availability, accessibility and utilization of information and communication technology in physics teaching in Akwa Ibom State, Nigeria, West Africa. Canadian Center of Science and Education, Modern Applied Science, 7(9), 57-62. https://doi.org/10.5539/mas.v7n9p57

Tella, A., Orim, F., Ibrahim, D. M., \& Memudu. S. D. (2017). The Use of Electronic Resources by Academic Staff at The University of Ilorin, Nigeria. Education and Information Technologies, 1-9. https://doi.org/10.1007/s10639-017-9577-2

Teo, T., Lee, C. B., \& Chai, C. S. (2008). Understanding Pre-service Teachers' Computer Attitudes: Applying and Extending the Technology Acceptance Model (TAM). Journal of Computer-Assisted Learning, 24, 128-143. https://doi.org/10.1111/j.13652729.2007.00247.x

Tezci, E. (2009). Teachers' Effect on ICT Use in Education: The Turkey Sample. Procedia Social and Behavioural Science, 1(2009), 1285-1294. https://doi.org/10.1016/j.sbspro.2009.01.228 